\title{
History and Future of Nucleic Acid Amplification Technology Blood Donor Testing
}

\author{
Willi Kurt Roth \\ GFE Blut, Frankfurt am Main, Germany
}

\author{
Keywords \\ Blood donation - Nucleic acid amplification technology . \\ Screening · Safety · History · Future
}

\section{Abstract}

The introduction of blood donor screening by virus nucleic acid amplification technology (NAT) in the mid to late 1990s was driven by the so-called AIDS and hepatitis $C$ virus (HCV) epidemic, with thousands of recipients of infected blood products and components. Plasma fractionators were the first to introduce NAT testing besides pathogen reduction procedures, to reduce the virus transmission risk through their products. To achieve a similar safety standard, NAT was then also introduced for labile blood components. German transfusion centres were the first to start in-house NAT testing of their donations in pools of up to 96 samples for HCV, hepatitis $B$ virus (HBV), and human immunodeficiency virus-1 (HIV-1). Years later the diagnostics industry provided commercial HCV and HIV-1 and later HBV NAT tests on automated platforms. NAT tests for HIV-2, hepatitis A virus, and Parvovirus B19 followed, again driven by transfusion centres with their in-house tests. When severe acute respiratory syndrome corona virus (SARS-CoV) and West Nile Virus emerged it was the NAT that enabled the manufacturers and transfusion centres to instantly introduce sensitive and specific screening tests. Subsequent automation including sample preparation has significantly reduced the costs and complexity of the procedure and made it affordable to middle income countries as well. Currently more than 60 million do-
\end{abstract}

nations per year are NAT tested worldwide and the remaining residual risk of virus transmission by blood components and products could be reduced to almost zero. Automation rendered possible the reduction of pool size in conjunction with increased throughput and sensitivity. Thus, antibody and antigen testing may be dispensable in the long run, particularly in the combination of NAT testing with pathogen reduction. There are new technologies on the horizon like digital droplet PCR, next-generation sequencing, lab-on-achip, and digital antigen assays, which are comparably sensitive. However, each of these has limitations, either in throughput, costs, automation, time to result, specificity, or the need for NAT as an integral part of the technology. Thus, NAT is still the shortest and most efficient means to the result. Donor screening NAT also contributed significantly to our knowledge on how fast viruses replicate, and on the respective diagnostic window. In conjunction with animal and patient studies, we have learned more about the minimal infectious dose and the epidemics in the donor population.

(c) 2019 S. Karger AG, Basel

\section{Introduction}

The polymerase chain reaction (PCR) invented by Kary Mullis and honoured with the noble prize is still the most relevant nucleic acid amplification technology (NAT) and has comprehensively revolutionized diagnostics in many areas [1]. Compared to alternative NATs, for example transcription-mediated amplifica-

\section{KARGER}

(C) 2019 S. Karger AG, Basel
Willi Kurt Roth 
tion (TMA), PCR could easier be established in-house in many laboratories worldwide with little effort and reasonable costs. With the invention of the real-time PCR, this technology became amenable to automation and it significantly reduced its inherent drawbacks [2]. Contamination of equipment and laboratories with amplification products (amplicons) could be minimized or even eliminated. Internal controls could easily be included and discriminated from the target sequences by labelling with different fluorophores. By multiplexing of PCRs several different viruses could be detected in parallel with one test and discriminated from each other by different labels. This readily available technology fuelled many applications requiring the highest sensitivity and specificity in conjunction with the highest throughput and reasonable cost. These technical advances paved the way during the past 2 decades to an unprecedented high level of blood safety.

\section{Results}

\section{NAT for Blood Donor Testing: The Triggers}

In the early 1980s data accumulated indicating that AIDS is an infectious disease caused by an unknown virus preferably spreading in the male homosexual community and which can also be transmitted by blood and blood products [3-5]. In the late 1980s publications reported on the worldwide identification in post-transfusion non-Anon-B hepatitis patients of high rates of antibodies against the newly identified hepatitis C virus (HCV) $[6,7]$. Similar high rates of up to $80 \%$ were observed in haemophiliacs $[8,9]$.

Such alarming data triggered studies on the residual risk of transfusion-transmitted $\mathrm{HCV}, \mathrm{HIV}-1$, and hepatitis B virus (HBV) infections. For Germany, a substantial risk of 1 in 260,000 per transfused blood units was reported, which seemed quite low and acceptable to the authors $[10,11]$.

However, this perception changed in Germany, particularly after a weekly magazine headlined: "The AIDS Scandal, Deadly Blood" [12]. The authors mentioned that they had already reported 10 years ago on the risk of transmitting HIV by blood products and that there had been more than 200 critical articles on that issue and nothing happened. A total of 1,500 haemophiliacs were HIV infected in Germany. The situation in the German blood transfusion field seemed absurd to the authors.

The following public awareness and political discussions had far-reaching consequences. A congressional investigation committee on HIV infections through blood and blood products was established. The final report of the committee stated that $60 \%$ of infections among recipients of blood and blood products in Germany could have been prevented [13]. Nobody was sued, because all involved federal and state authorities, the industry, health insurance, hospitals, and the Red Cross had performed inadequately.

A list of recommendations was suggested on how to increase blood safety [13]. The most relevant were: a new Transfusion Law should be adopted in addition to modifications of the existing German Medicines Law; the PaulEhrlich-Institute (PEI) should be established as the new Senior Federal Authority for blood and blood products; the PEI should, in collaboration with the German medical association, release guidelines defining the latest standards prevailing in science and technology in transfusion medicine; surveillance of transfusion risks should be implemented; and most importantly, reversal of evidence and damage compensation should be implemented into German Medicines Law.

Most of the recommendations were adopted and motivated manufacturers and blood establishments to introduce new technologies with the potential to reasonably increase blood safety. Costs became secondary.

Since HCV - and HIV-1-contaminated blood products were distributed worldwide, many other countries were affected. HIV-contaminated blood products had even knowingly been administered to haemophiliacs in France and 4,000 patients were infected $[13,14]$. In the USA 10,000 were infected, while in Italy, the UK, and Spain around 1,300 were infected, respectively $[13,14]$.

NAT testing of batches of clotting factors, immunoglobulins, and production pools revealed high HCV contamination rates, particularly in those which were not inactivated [15-18]. These findings promoted the idea of testing donor blood by NAT in addition to antibody and antigen testing before the manufacturing process begins. In the mid-1990s, the Committee for Proprietary Medicinal Products (CPMP) pushed HCV NAT for manufacturing plasma pool testing in order to identify virus-contaminated batches of source material for the manufacture of blood products which were distributed worldwide. "From the 1st of July 1999 only batches derived from plasma pools tested and found non-reactive for HCV RNA by NAT ... should be batch released by marketing authorisation holder" [19]. The detection limit of the assay should be equivalent to a run control with an HCV RNA content of $100 \mathrm{IU} / \mathrm{mL}$. Pretesting of mini pools was encouraged in order to prevent the contamination of production pools with thousands of litres of plasma [19].

Consequently, manufacturers implemented pretesting of quite large mini pools consisting of samples from hundreds of donations. Blood establishments selling plasma for fractionation had to provide separate plasma samples for pooling and testing. This complicated logistics and increased costs for both sides. To reduce expenditure, manufacturers offered higher rates for plasma pretested 
by NAT. Blood centres selling plasma for fractionation were therefore interested in establishing their own inhouse NAT pretesting of mini pools which could also be adopted for labile components. In contrast to fractionation plasma, platelets have a shelf life of days and results should be available before pooled platelets are manufactured. Thus, the time to result had to be condensed to less than 1 working day. Consequently, the pool size had to be reduced and pool resolution accelerated. Smaller pools of up 96 samples caused increased throughput, workload, and costs, but reduced the number of donations on hold if a pool tested positive. This improved the blood supply and simplified platelet production. More importantly, the reduction of the pool size increased sensitivity and product safety.

However, the methods were manual and cumbersome, logistics complicated, and commercial assays were not available. Several diagnostic companies invited by blood establishments to collaborate in applying their NAT assays for blood donation screening argued that the technology was still too immature and development costs would never pay back.

\section{Feasibility Studies and First Results}

Initial publications on the application of in-house approaches for mini pool plasma testing confirmed concerns about the maturity of PCR testing in a blood bank setting. PCR was well established for patient diagnostics; however, screening of thousands of healthy and mostly negative blood donors per day required quite different approaches. Repeat testing was no option and therefore false negatives had to be avoided. Thus, screening of blood donors required the highest sensitivity and specificity, highest throughput, shortest time to result, and lowest costs, which altogether were quite challenging.

The usefulness of the direct virus detection by PCR for blood donor screening was already reported in the mid1990s for single donation testing [20,21]. In 1998, the first data were published on the routine screening of mini pools of up to 600 donations for HCV, HBV, and HIV-1 by PCR, with a throughput of 3,000 samples per day. Among 430 thousand donations tested and negative in serological assays, 0 were HIV-1, 2 were HBV, and 22 were HCV positive by PCR only [22]. These high numbers of HCV PCR-only positives exceeded by a factor of 10 the estimated yield rate of HCV seronegative/PCR positive donations in Germany according to previous publications $[10,11]$. However, a further study performed on smaller pools of 96 samples reported no viremic seronegative donation among 332 thousand tested, which was below the expected number [23].

The first data demonstrating the reliability and feasibility of blood donor screening by PCR were published in 1999 after the testing of 373 thousand donations. Pools of
96 were virus enriched by simplified centrifugation and tested for HCV, HBV, and HIV-1. Two were HCV NATonly positive, which was close to the estimated rate of 1 in 200 thousand [24].

Based on these accumulating data and following the CPMP regulations for source plasma, the PEI mandated from July 1, 1999 the HCV NAT testing of labile blood components in Germany with a detection limit of 5,000 $\mathrm{IU} / \mathrm{mL}$ per individual donation [25]. The PEI wisely abstained from mandating a pool size for blood screening with the intention to leave open the field for different technological and logistical approaches. HBV and HIV1 NAT were not mandated at that time despite the fact that PCR screening of blood donations with in-house assays for all three transfusion-relevant viruses had voluntarily been introduced in the majority of blood establishments years before [22-24]. Commercial assays for HIV-1 and HBV were not available and not all blood banks had access to in-house methods. HIV-1 NAT was mandated in Germany in 2004 and anti-HBc testing in 2006. HBV NAT is not yet envisaged as a mandatory test in Germany.

\section{Progress and Introduction World Wide}

After the demonstration of feasibility and efficacy of blood donation screening by in-house assays in Germany, the diagnostic NAT test manufacturers started validation of their assays for blood screening as well [26]. It took years and NAT testing of HCV and HIV-1 was not introduced in other countries before 1999, except Austria, from where blood centres sent their samples to Germany for testing (Fig. 1). Commercial HBV NAT assays for blood screening became available many years later (Fig. 1).

The superior sensitivity of the PCR resulted in a serious drawback: it was highly contamination prone by its own amplicons, which could evade into the laboratory upon opening the vial for detection. If laboratories were contaminated, the blood supply was in danger. This problem could be solved almost completely by the invention of real-time PCR, which enabled detection of the amplicons without opening the reaction tube [2]. Blood banks were the first to adopt the technology for their in-house NAT [27, 28]. Real-time PCR also paved the way to an increasing degree of automation and noticeable cost reduction.

This technological progress came along with an increasing regulatory standardization process. "An international working group on standardization of genomic amplification techniques (SoGAT) was established in 1995 on behalf of the WHO, and has since been coordinated by the National Institute for Biological Standards and Control (NIBSC) (UK)" [29]. The group focussed on the development of international standards (IS) for blood 


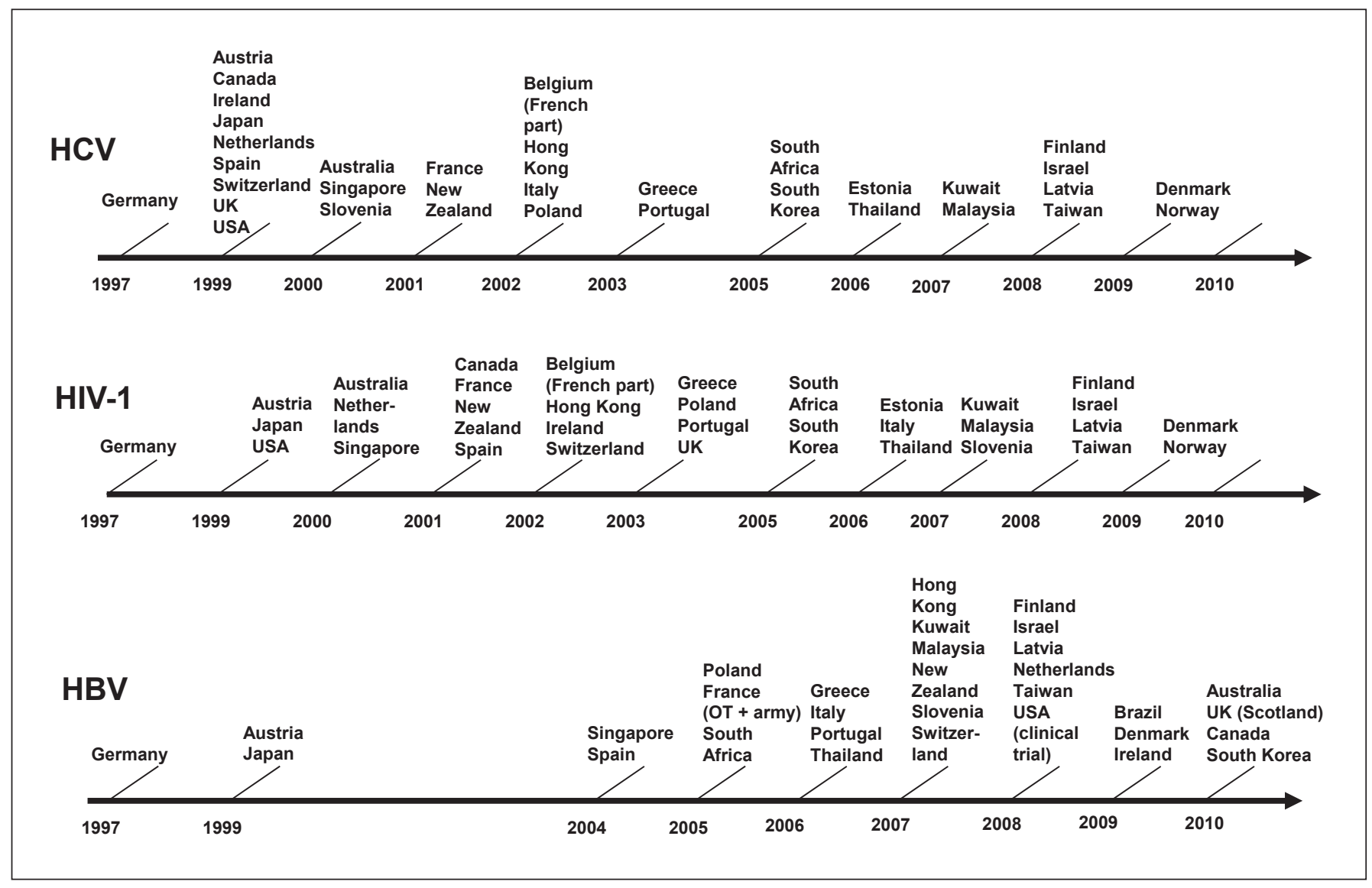

Fig. 1. Timetable of the introduction of NAT blood donation testing by virus and country up to 2010. Thirtythree countries and 1.15 billion populations were covered. ${ }^{\circledR}$ John Wiley and Sons, reproduced with kind permission from Roth et al. [32].

screening with the first HCV WHO standard for NAT assays established in 1997, and for HBV and HIV-1 in 1999 [29]. The WHO IS are the highest measurement standards in internationally agreed arbitrary units determined by international collaborative studies. The panel of standards was continuously expanded to more transfusion-relevant viruses and can be used for secondary standards for run controls and assay calibration/validation. In conjunction with genotype and seroconversion panels they contributed to the current high standard of commercial and in-house NAT assays.

In-house donor screening NAT remained a specific German approach despite increasing in vitro diagnostics regulations. German blood centres were the first to introduce HCV, HBV, and HIV-1 NAT and the first to introduce HIV-2, hepatitis A virus, and Parvovirus B 19 NAT. As soon as the commercial manufacturers were able to provide test kits and instruments adapted to the specific requirements of blood banks, more and more countries followed and introduced NAT testing (Fig. 1). Currently, more than 60 million donations per year are tested worldwide.

\section{Impact on Viral Safety}

Despite continuing concerns on the cost-benefit ratio of NAT testing, the yield of seronegative, NAT-only positive donations was substantial and finally convinced its critics. The highest yield has expectedly been obtained with HCV NAT according to the long pre-seroconversion window, the explosive ramp-up phase, and high plateau phase concentration of HCV. The first comprehensive data on the NAT yield were reported in 2008 from Germany and revealed $23 \mathrm{HCV}, 7 \mathrm{HIV}-1$, and $43 \mathrm{HBV}$ NAT-only positives among 30 million tested donations [30]. In the USA, $244 \mathrm{HCV}$ and $32 \mathrm{HIV}-1 \mathrm{NAT}$-only positives were identified among 66 million tested, as reported in 2010 [31]. HBV testing was not implemented in the USA at that time. The International Society of Blood Transfusion (ISBT) working party on transfusion-transmitted infectious diseases (WP-TTID) performed an "international survey on NAT testing of blood donations: expanding implementation and yield from 1999-2009." Data from 33 countries which had introduced NAT testing were collected, covering 300 million donations which were NAT tested since its introduction [32]. Within 10 
Table 1. Yield of blood donation NAT testing worldwide since introduction and in 2008

\begin{tabular}{|c|c|c|c|c|c|}
\hline Virus & Period & $\begin{array}{l}\text { Tested } \\
\text { donations, } \\
n\end{array}$ & $\begin{array}{l}\text { NAT-only } \\
\text { positives, } \\
n\end{array}$ & $\begin{array}{l}\text { NAT-only } \\
\text { positives/ } \\
\text { million }\end{array}$ & $\begin{array}{l}\text { Rate } \\
2008 / \\
\text { total }\end{array}$ \\
\hline \multirow[t]{2}{*}{ HIV } & total & $272,520,696$ & 244 & 0.90 & \multirow[t]{2}{*}{2.14} \\
\hline & 2008 & $37,356,757$ & 72 & 1.93 & \\
\hline \multirow[t]{2}{*}{$\mathrm{HCV}$} & total & $303,196,074$ & 680 & 2.24 & \multirow[t]{2}{*}{0.83} \\
\hline & 2008 & $37,095,225$ & 69 & 1.86 & \\
\hline \multirow[t]{2}{*}{$\mathrm{HBV}$} & total & $114,286,214$ & 1,884 & 16.48 & \multirow[t]{2}{*}{0.52} \\
\hline & 2008 & $19,887,649$ & 169 & 8.50 & \\
\hline
\end{tabular}

From Roth et al. [32].

years a total of 2,808 virus-contaminated donations were identified which would have been transfused without NAT (Table 1).

Despite constantly decreasing costs and increasing automation, most German blood centres preferred to test donations in mini pools of 96 , mainly because of the high sample numbers per day and the broad range of viruses they test for. This is justified and substantiated by the extremely low rate of only $1 \mathrm{HCV}$ and $2 \mathrm{HIV}-1$ transmissions observed in Germany since NAT testing has commenced [33-35]. It also justifies the moderate NAT limit of detection mandated by the PEI for HCV and HIV-1 of 5,000 and $10,000 \mathrm{IU} / \mathrm{mL}$ per individual donation, respectively. Only the HCV transmitting donation had a low viral load which was even below the LOD of the most sensitive single donation test kits [33].

The HIV-1 transmissions, however, were due to mutations in the primer/probe binding sites resulting in false negative NAT test results [34]. Since surveillance revealed many more test failures in Germany, fortunately without transmission, the PEI mandated at least dual target NAT to prevent false negatives if one genomic region would be mutated such that primers/probes cannot bind $[35,36]$. However, one NAT company introduced a triple target HIV-1 PCR. They analysed NAT test failures and identified two new HIV-1 clade B isolates that were highly mutated even in the most conserved regions, raising concerns about sufficient sequence coverage with only two independent amplicons [37].

The impact of NAT testing on blood safety was not restricted to the well-known transfusion-relevant viruses. In the past 2 decades new viruses emerged and "old" ones re-emerged with varying impact on blood safety.

A West Nile Virus epidemic broke out in 1999 in New York and reached the west coast in 2002, hitting a naïve population with thousands of infected people. Targeted testing of blood donors by NAT was rapidly implemented with a combination of mini pool testing and switching to sensitive single-donation testing after the first reactive mini pool was identified [38]. Since then only three transmissions have occurred through blood components, clearly demonstrating the high contribution of NAT testing to blood safety [39].

The severe acute respiratory syndrome coronavirus (SARS-CoV) emerged in China in November 2002 and was first reported in February 2003 [40]. The rapid provision of sensitive and specific diagnostic tests was of utmost importance to halt the epidemic. Only NAT tests could instantly be developed and provided for patient and blood donor diagnostics [40, 41]. By the end of 2003 the outbreak was contained [40].

Recent studies revealed a high percentage of hepatitis E virus (HEV)-infected blood donors and frequent transmission of the virus by blood components in Europe and many other countries worldwide [42-44]. Some countries have already introduced HEV NAT screening of blood donations, including the UK, Ireland, the Netherlands [44], and recently Switzerland. In Germany, the PEI intends to mandate HEV NAT screening in October 2019 according to a phased plan [42]. This underlines the importance of NAT testing, which is the only countermeasure to reduce the transmission risk [43, 44].

NAT tests for many more emerging and re-emerging viruses have been developed suitable for blood screening, including cytomegalovirus, Chikungunya virus, Dengue virus, and most recently the ZIKA virus. In case of an outbreak of an unknown virus, NAT tests can instantly be developed as soon as the genome sequence is identified, making blood safer than ever before.

\section{Scientific Advances through Blood Donation NAT}

Blood donation NAT testing has not only increased blood safety, but has also provided insights into the epidemiology, natural history, and pathogenesis of viral infection [45]. In particular, our knowledge on how viruses replicate and on the respective diagnostic window has expanded. Analysing seroconversion panels obtained from frequent source plasma donors by quantitative and qualitative NAT revealed a very long pre-seroconversion window of 59 days on average, and a high replication rate of HCV with a doubling time of $10.8 \mathrm{~h}[46,47]$. Similar studies were performed with panels from HBV and HIV-1 infected donors revealing doubling times of 3.9 and 0.9 days, respectively [48]. These data allow estimating by back calculation the reduction of the pre-seroconversion window by NAT assays and the residual window of the NAT test itself dependent on the sensitivity of the respective test. Blood donation NAT has also triggered studies on the minimal infectious dose of the different viruses which has a direct impact on blood safety through the required LOD of NAT tests to reach zero risk. The infectious dose for HIV-1 was calculated by reverse probit 
analysis of the viral load of transmitting and non-transmitting donations, resulting in a $50 \%$ minimal infectious dose of about 400 virions [49]. However, considerably lower concentrations were found to be infectious [34,50].

The minimal infectious dose of HBV assessed in the chimpanzee and humanized mouse models were in good accordance. Between 1 and 10 copies of HBV DNA from the ramp-up phase caused HBV infection after inoculation into chimeric mice and chimpanzees [51,52]. However, samples taken from the late antibodies against hepatitis B core antigen (anti- $\mathrm{HBc}$ )-positive tail end phase were 100-times less infectious [51]. The HCV minimal infectious dose determined in chimpanzees was 20 copies [53].

The frequent occurrence of chronic occult HBV infection either anti-HBc positive or negative was well-known. Donor screening revealed that acute occult HBV infection occurs as well [54]. Such donors present with a low and transient hepatitis B viremia but are HBsAg and ALT negative. They are infectious during the viremic phase, and late seroconversion to anti-HBs and/or anti-HBc positivity can be observed [54].

The introduction of HCV NAT, HCV antibody/antigen combo assays, and anti-HBc testing made non-specific ALT testing superfluous and the regulatory requirement was discontinued in Germany in 2004. It is now debated if HBV NAT can replace HBsAg testing. Sensitive HBV NAT has proven to interdict efficiently HBV transmissions by pre-seroconversion window donations, and anti-HBc testing is highly sensitive and sufficiently specific in detecting chronic occult carriers with low level viremia [55]. HBsAg testing simply doubles screening for the virus with no obvious advantage in sensitivity compared to NAT testing [55]. Discontinuing HBsAg testing would save money since HBV NAT is included in all commercial NAT test kits designed for blood screening and does not cost extra.

\section{Alternative Technologies}

Science and technology has advanced rapidly since the introduction of virus NAT testing in transfusion medicine. Twenty years after real-time PCR and TMA were introduced, blood donation screening is almost completely automated and covers a broad panel of viruses that can be tested in parallel. The residual risk of transfusiontransmitted viruses has been reduced by NAT to almost zero. Bacteria have now become the most relevant and most challenging pathogens in transfusion medicine, with transmission rates exceeding that of viruses by orders of magnitude. Pathogen reduction measures are effective for viruses and bacteria as well. However, there are resistant viruses and bacteria which can only be reduced and not entirely inactivated. NAT for bacteria would require only 1 generic NAT test directed to the highly con- served 16 or $23 \mathrm{~S}$ genes. However, donor screening is not yet feasible due to background DNA. Bacterial DNA is present in the air, in water, and particularly in DNA polymerase preparations which are derived from bacteria. These sequences contaminate PCR reagents and are coamplified, thereby impairing the detection limit.

The array technology could potentially circumvent these drawbacks because it specifically detects thousands of different genes or agents, for example all transfusionrelevant viruses and bacteria, from one sample. However, volumes that can be processed are tiny, reducing the chance to detect small copy numbers in donor samples during the early phase of infection, even if amplification by NAT precedes array detection to increase sensitivity. Moreover, amplification with subsequent array detection prolongs the time to result and increases costs.

Comparable shortcomings argue against next-generation sequencing (NGS) as an alternative to NAT in donation screening. This massively parallel or deep sequencing provides access to the whole genome or whole microbiome in a single sample. Time to the result has been significantly reduced and prices have become more affordable. Independent of the supplier's technology, several measures have to be performed in any of these methods: starting with fragmentation, adapter ligation and annealing, solid-phase amplification on a slide (e.g., Illumina) or emulsion amplification on beads (e.g., Roche 454 , Ion Torrent) is required before sequencing with, for example, fluorescent nucleotides (Illumina) or $\mathrm{pH}$ shift (Ion Torrent) can be commenced. Computation (alignment and data analysis) completes the procedure, which is largely automated. What would be the rationale in blood screening for all that expensive and time-consuming labour before and after the amplification if we can have the result directly in real-time with conventional NAT? Costs are far higher than with NAT alone and most probably will not come down to the same level. Throughput with thousands of samples per shift is still a challenge and sensitivity is not yet competitive.

An alternative approach would be high-throughput digital droplet PCR. Besides high numbers of different targets that can be amplified in parallel, the reaction time is reduced to minutes instead of hours in conventional PCR. However, the volumes that can be processed are in the nanolitre range, making its sensitivity not competitive. Digital droplet PCR has been designed primarily for exact quantification at high sensitivity. In blood donation screening it will have similar shortcomings as the array technology or NGS.

Digital ELISA or single-molecule array (Simoa) by Quanterix is very promising as it is 1,000 times more sensitive than conventional ELISA and it is sufficiently fast. Its capabilities have already been demonstrated for HIV1 detection with high sensitivity [56]. There is, however, 
concern about its specificity and high-throughput automation for multiple targets is not yet available.

A number of alternative NAT methods have been developed, mostly isothermal procedures. However, none of these have been developed to a similar maturity for blood screening as PCR and TMA. They have no advantage in sensitivity or specificity, in speed or multiplexing capability, or in the automation level and costs.

\section{Future Scenarios}

Since blood donation NAT has already reached the ultimate goal in diagnostics of detecting $1 \mathrm{DNA} / \mathrm{RNA}$ molecule if present in the reaction tube, progress most probably will be made around this ground-breaking technology. This may include increased multiplexing capabilities and total lab automation, which are particularly attractive for big blood centres with thousands of samples per day. For small- and medium-sized blood banks, small benchtop devices with high flexibility and a broad range of assays, which can be used for both patient diagnostics and blood donor screening, would be preferable.

To achieve real zero transmission risk in transfusion medicine would require extracting nucleic acids from at least $10 \mathrm{~mL}$ of donor plasma, the minimum volume transfused with red cells. Since one copy of the relevant viruses may be infectious (see above), the volume must be reduced to a small amount transferable to the reaction tube without losses of nucleic acids. This would require highvolume extraction methods or repeat testing of small volumes from a single sample. Both are technically very challenging and may not be necessary. If pathogen reduction also succeeds for red cells, it would be sufficient to apply NAT that is able to detect donations with a viral load exceeding the inactivation capacity of the respective method. Mini pool NAT with moderate sensitivity would suffice, making expensive single donation NAT superfluous. The application of both methods to donated blood would enable us to reach the ultimate goal of zero viral risk and serological testing could be discontinued.

A similar approach could be envisaged for bacteria testing but is less realistic. Bacteria were shown to grow even after inactivation from very low numbers of surviving spores which cannot be detected by NAT or any oth- er method simply due to the high sample volumes needed $[57,58]$. Screening all donations with bacteria NAT would thus be a waste of time and resources. Bacteria preferably grow in platelets and may have a long lag phase before they start with exponential growth. It would be advisable to delay testing until bacteria have grown up to higher numbers and to perform testing as late as possible just before the component is transfused. Such a pre-release or bedside test would require a fast, straightforward method, preferably taking minutes only. Moderate sensitivity and limited throughput would suffice. Such methods are on the horizon but not yet ready for blood screening.

\section{Conclusion}

The history of blood donation NAT dates back to the late 1980s, when PCR was used to identify post-transfusion HCV and HIV-1 transmission rates in blood component, clotting factor, and immunoglobulin recipients. The AIDS and HCV epidemic triggered worldwide measures to increase blood safety and made concerns about the cost-benefit ratio secondary. Plasma fractionators were the first to introduce NAT testing of their production pools to make, in conjunction with pathogen inactivation, blood products as safe as possible. To achieve a similar safety standard, blood donation centres adopted the technology for the testing of labile components. Since no commercial assays were available they invested high amounts of money and established in-house NAT tests for screening of their donations. It took years until the industry developed commercial test kits that were suitable for blood screening and that covered a sufficiently broad range of transfusion-relevant viruses. Increasing automation and significant price reductions made the technology amenable to an increasing number of countries. The yield of serologically negative NAT-only positive donations was convincing and facilitated its acceptance. Virus transmission risk could be reduced to almost zero. Upon the introduction of universal pathogen reduction in conjunction with NAT testing, the ultimate goal of zero risk could be achieved and serological testing would be dispensable.

\section{References}

1 Saiki RK, Scharf S, Faloona F, Mullis KB, Horn GT, Erlich HA, et al. Enzymatic amplification of beta-globin genomic sequences and restriction site analysis for diagnosis of sickle cell anemia. Science. 1985 Dec; 230(4732):1350-4.

2 Higuchi R, Dollinger G, Walsh PS, Griffith R. Simultaneous amplification and detection of specific DNA sequences. Biotechnology (N Y). 1992 Apr;10(4):413-7.
3 Gottlieb MS, Schroff R, Schanker HM, Weis man JD, Fan PT, Wolf RA, et al. Pneumocystis carinii pneumonia and mucosal candidiasis in previously healthy homosexual men: evidence of a new acquired cellular immunodeficiency. N Engl J Med. 1981 Dec;305(24): 1425-31.
4 Centers for Disease Control (CDC). Update on acquired immune deficiency syndrome (AIDS) among patients with haemophilia A. MMWR Morb Mortal Wkly Rep. 1982 Dec; 31(48):644-6, 652.

5 Centers for Disease Control (CDC). Epidemiologic notes and reports possible transfusionassociated acquired immune deficiency syndrome (AIDS) - California. MMWR Morb Mortal Wkly Rep. 1982 Dec;31(48):652-4. 
6 Kuo G, Choo QL, Alter HJ, Gitnick GL, Redeker AG, Purcell RH, et al. An assay for circulating antibodies to a major etiologic virus of human non-A, non-B hepatitis. Science. 1989 Apr;244(4902):362-4.

7 Esteban JI, González A, Hernández JM, Viladomiu L, Sánchez C, López-Talavera JC, et al. Evaluation of antibodies to hepatitis C virus in a study of transfusion-associated hepatitis. N Engl J Med. 1990 Oct;323(16):110712.

8 Schramm W, Roggendorf M, Rommel F, Kammerer R, Pohlmann H, Rasshofer R, et al. Prevalence of antibodies to hepatitis $\mathrm{C}$ virus (HCV) in haemophiliacs. Blut. 1989 Oct; 59(4):390-2.

9 Makris M, Preston FE, Triger DR, Underwood JC, Choo QL, Kuo G, et al. Hepatitis C antibody and chronic liver disease in haemophilia. Lancet. 1990 May;335(8698):1117-9.

10 Kubanek B, Cardoso M, Glück D, Koerner K. [Risk of infection transmission by blood components]. Infusionsther Transfusionsmed. 1993 Apr;20(1-2):54-9. German.

11 Sibrowski W, Penner M, Kühnl P. [Transfusion-induced virus infections: how great is the risk?]. Infusionsther Transfusionsmed. 1993 Jun;20 Suppl 2:4-9. German.

12 Hausmitteilung. Der Spiegel. 1993;41.

13 Deutscher Bundestag 12. Wahlperiode: Zweite Beschlussempfehlung und Schlussbericht des 3. Untersuchungsausschusses nach Artikel 44 des Grundgesetzes. Drucksache 12/8591. Bonn; 1994 Oct 21.

14 Wikipedia: Infektionen durch HIV-kontaminierte Blutprodukte

15 Centers for Disease Control and Prevention (CDC). Outbreak of hepatitis C associated with intravenous immunoglobulin administration - United States, October 1993 - June 1994. MMWR Morb Mortal Wkly Rep. 1994 Jul;43(28):505-9.

16 Yap PL, McOmish F, Webster AD, Hammarstrom L, Smith CI, Bjorkander J, et al. Hepatitis $\mathrm{C}$ virus transmission by intravenous immunoglobulin. J Hepatol. 1994 Sep;21(3): 455-60.

17 Bjøro K, Frøland SS, Yun Z, Samdal HH, Haaland $\mathrm{T}$. Hepatitis $\mathrm{C}$ infection in patients with primary hypogammaglobulinemia after treatment with contaminated immune globulin. $\mathrm{N}$ Engl J Med. 1994 Dec;331(24):1607-11.

18 Makris M, Garson JA, Ring CJ, Tuke PW, Tedder RS, Preston FE. Hepatitis C viral RNA in clotting factor concentrates and the development of hepatitis in recipients. Blood. 1993 Apr;81(7):1898-902.

19 EMEA. CPMP/BWP/390/97: note for guidance on the introduction of nucleic acid amplification technology (NAT) for the detection of hepatitis $\mathrm{C}$ virus RNA in plasma pools. London: EMEA; 2001.

20 Saldanha J, Minor P. A sensitive PCR method for detecting HCV RNA in plasma pools, blood products, and single donations. J Med Virol. 1994 May;43(1):72-6.

21 Wolff C, Hörnschemeyer D, Skurtopulos M, Petersen N, Beyer J, Seidel K, et al. [Molecular biological screening of viruses important to transfusion medicine]. Beitr Infusionsther Transfusionsmed. 1994;32:102-9. German.
22 Schottstedt V, Tuma W, Bünger G, Lefèvre H PCR for HBV, HCV and HIV-1 experiences and first results from a routine screening programme in a large blood transfusion service. Biologicals. 1998 Jun;26(2):101-4.

23 Cardoso MS, Koerner K, Kubanek B. Minipool screening by nucleic acid testing for hepatitis $B$ virus, hepatitis $C$ virus, and HIV: preliminary results. Transfusion. 1998 Oct; 38(10):905-7.

24 Roth WK, Weber M, Seifried E. Feasibility and efficacy of routine PCR screening of blood donations for hepatitis $\mathrm{C}$ virus, hepatitis B virus, and HIV-1 in a blood-bank setting. Lancet. 1999 Jan;353(9150):359-63.

25 Löwer J. Abwehr von Arzneimittelrisiken Verminderung des Risikos von Hepatitis C Virus - Kontaminationen in Erythrozytenzonzentraten. Bundesanzeiger. 1998;53:3835.

26 Sun R, Schilling W, Jayakar H, Ku J, Wang J, Rosenstraus M, et al. Simultaneous extraction of hepatitis $\mathrm{C}$ virus (HCV), hepatitis $\mathrm{B}$ virus, and HIV-1 from plasma and detection of HCV RNA by a reverse transcriptase-polymerase chain reaction assay designed for screening pooled units of donated blood. Transfusion. 1999 Oct;39(10):1111-9.

27 Drosten C, Seifried E, Roth WK. TaqMan $5^{\prime}$-nuclease human immunodeficiency virus type 1 PCR assay with phage-packaged competitive internal control for high-throughput blood donor screening. J Clin Microbiol. 2001 Dec;39(12):4302-8.

28 Hennig H, Luhm J, Hartwig D, Klüter $H$, Kirchner H. A novel RT-PCR for reliable and rapid HCV RNA screening of blood donations. Transfusion. 2001 Sep;41(9):1100-6.

29 Baylis SA, Wallace P, McCulloch E, Niesters HG, Nübling CM. Standardization of nucleic acids tests: the approach of the World Health Organization. J Clin Microbiol. 2019 Jan; 57(1):e01056-18.

30 Hourfar MK, Jork C, Schottstedt V, WeberSchehl M, Brixner V, Busch MP, et al.; German Red Cross NAT Study Group. Experience of German Red Cross blood donor services with nucleic acid testing: results of screening more than 30 million blood donations for human immunodeficiency virus-1, hepatitis $\mathrm{C}$ virus, and hepatitis $\mathrm{B}$ virus. Transfusion. 2008 Aug;48(8):1558-66.

31 Zou S, Dorsey KA, Notari EP, Foster GA, Krysztof DE, Musavi F, et al. Prevalence, incidence, and residual risk of human immunodeficiency virus and hepatitis $\mathrm{C}$ virus infections among United States blood donors since the introduction of nucleic acid testing. Transfusion. 2010 Jul;50(7):1495-504.

32 Roth WK, Busch MP, Schuller A, Ismay S, Cheng A, Seed CR, et al. International survey on NAT testing of blood donations: expanding implementation and yield from 1999 to 2009. Vox Sang. 2012 Jan;102(1):82-90.

33 Nübling CM, Heiden M, Chudy M, Kress J, Seitz R, Keller-Stanislawski B, et al. Experience of mandatory nucleic acid test (NAT) screening across all blood organizations in Germany: NAT yield versus breakthrough transmissions. Transfusion. 2009 Sep;49(9): 1850-8.
34 Schmidt M, Korn K, Nübling CM, Chudy M, Kress J, Horst HA, et al. First transmission of human immunodeficiency virus Type 1 by a cellular blood product after mandatory nucleic acid screening in Germany. Transfusion. 2009 Sep;49(9):1836-44.

35 Chudy M, Kress J, Halbauer J, Heiden M, Funk MB, Nübling CM. Risk Minimization Measures for Blood Screening HIV-1 Nucleic Acid Amplification Technique Assays in Germany. Transfus Med Hemother. 2014 Feb; 41(1):45-51.

36 Cichutek K. Anordnung von Massnahmen zur Risikominimierung beim Einsatz von HIV-1 NAT-Testsystemen. BAnz AT. 2012 Sept 12:B6.

37 Zolt SD, Thermann R, Bangsow T, Pichl L, Müller B, Jork C, et al. Implementation of an HIV-1 Triple-Target NAT Assay in the Routine Screening at Three German Red Cross Blood Centres. Transfus Med Hemother. 2016 May;43(3):183-9.

38 Busch MP, Caglioti S, Robertson EF, McAuley JD, Tobler LH, Kamel H, et al. Screening the blood supply for West Nile virus RNA by nucleic acid amplification testing. $\mathrm{N}$ Engl J Med. 2005 Aug;353(5):460-7.

39 Lai L, Lee TH, Tobler L, Wen L, Shi P, Alexander J, et al. Relative distribution of West Nile virus RNA in blood compartments: implications for blood donor nucleic acid amplification technology screening. Transfusion. 2012 Feb;52(2):447-54.

40 Berger A, Drosten C, Doerr HW, Stürmer M, Preiser W. Severe acute respiratory syndrome (SARS) - paradigm of an emerging viral infection [Review]. J Clin Virol. 2004 Jan;29(1): 13-22.

41 Schmidt M, Brixner V, Ruster B, Hourfar MK, Drosten C, Preiser W, et al. NAT screening of blood donors for severe acute respiratory syndrome coronavirus can potentially prevent transfusion associated transmissions. Transfusion. 2004 Apr;44(4):470-5.

42 Funk M. Abwehr von Arzneimittelrisiken. Stufenplan Stufe 2: Anhörung zur Einführung Risikominimierender Maßnahmen zur Prävention von Übertragungen des HepatitisE-Virus durch Blutkomponenten zur Transfusion und von Stammzellzubereitungen zur hämatopoetischen Rekonstitution. Langen: Paul-Ehrlich-Institut; 2018.

43 Dreier J, Knabbe C, Vollmer T. Transfusiontransmitted hepatitis E: NAT screening of blood donations and infectious dose. Front Med. 2018 Feb;5:5.

44 Domanović D, Tedder R, Blümel J, Zaaijer H, Gallian P, Niederhauser C, et al. Hepatitis E and blood donation safety in selected European countries: a shift to screening? Euro Surveill. 2017 Apr;22(16):30514.

45 Busch MP. Insights into the epidemiology, natural history and pathogenesis of hepatitis $C$ virus infection from studies of infected donors and blood product recipients. Transfus Clin Biol. 2001 Jun;8(3):200-6.

46 Nübling CM, Unger G, Chudy M, Raia S, Löwer J. Sensitivity of HCV core antigen and HCV RNA detection in the early infection phase. Transfusion. 2002 Aug;42(8):1037-45. 
47 Glynn SA, Wright DJ, Kleinman SH, Hirschkorn D, Tu Y, Heldebrant C, et al. Dynamics of viremia in early hepatitis $C$ virus infection. Transfusion. 2005 Jun;45(6):994-1002.

48 Fiebig EW, Wright DJ, Rawal BD, Garrett PE, Schumacher RT, Peddada L, et al. Dynamics of HIV viremia and antibody seroconversion in plasma donors: implications for diagnosis and staging of primary HIV infection. AIDS, 2003 Sep;17(13):1871-9.

49 Kleinman SH, Lelie N, Busch MP. Infectivity of human immunodeficiency virus-1, hepatitis $C$ virus, and hepatitis $B$ virus and risk of transmission by transfusion. Transfusion. 2009 Nov;49(11):2454-89.

50 Delwart EL, Kalmin ND, Jones TS, Ladd DJ, Foley B, Tobler LH, et al. First report of human immunodeficiency virus transmission via an RNA-screened blood donation. Vox Sang. 2004 Apr;86(3):171-7.
51 Tabuchi A, Tanaka J, Katayama K, Mizui M, Matsukura H, Yugi H, et al. Titration of hepatitis $B$ virus infectivity in the sera of pre-acute and late acute phases of HBV infection: transmission experiments to chimeric mice with human liver repopulated hepatocytes. J Med Virol. 2008 Dec;80(12):2064-8.

52 Komiya Y, Katayama K, Yugi H, Mizui M, Matsukura $\mathrm{H}$, Tomoguri T, et al. Minimum infectious dose of hepatitis B virus in chimpanzees and difference in the dynamics of viremia between genotype $\mathrm{A}$ and genotype $\mathrm{C}$. Transfusion. 2008 Feb;48(2):286-94.

53 Katayama K, Kumagai J, Komiya Y, Mizui M, Yugi H, Kishimoto S, et al. Titration of hepatitis $\mathrm{C}$ virus in chimpanzees for determining the copy number required for transmission. Intervirology. 2004;47(1):57-64

54 Yoshikawa A, Gotanda Y, Minegishi K, Taira R, Hino S, Tadokoro K, et al.; Japanese Red Cross NAT Screening Research Group. Lengths of hepatitis B viremia and antigenemia in blood donors: preliminary evidence of occult (hepatitis B surface antigen-negative) infection in the acute stage. Transfusion. 2007 Jul;47(7):1162-71.
55 Roth WK, Weber M, Petersen D, Drosten C, Buhr S, Sireis W, et al. NAT for HBV and anti-HBc testing increase blood safety. Transfusion. 2002 Jul;42(7):869-75.

56 Passaes CP, Bruel T, Decalf J, David A, Angin $\mathrm{M}$, Monceaux V, et al.; ANRS RHIVIERA Consortium. Ultrasensitive HIV-1 p24 Assay Detects Single Infected Cells and Differences in Reservoir Induction by Latency Reversal Agents. J Virol. 2017 Feb;91(6):e02296-16.

57 Schmidt M, Hourfar MK, Sireis W, Pfeiffer U, Göttig S, Kempf VA, et al. Evaluation of the effectiveness of a pathogen inactivation technology against clinically relevant transfusiontransmitted bacterial strains. Transfusion. 2015 Sep;55(9):2104-12.

58 Montag T, Nicol SB, Schurig U, Heiden M, Huber H, Sanzenbacher R, et al. Microbial safety of cell based medicinal products-what can we learn from cellular blood components? [Review]. Clin Chem Lab Med. 2008; 46(7):963-5. 